\title{
Hydropic vacuolation in the liver of three species of fish from the U.S. West Coast: lesion description and risk assessment associated with contaminant exposure
}

\author{
C. M. Stehr*, L. L. Johnson, M. S. Myers \\ Northwest Fisheries Science Center, National Marine Fisheries Service, National Oceanic and Atmospheric Administration, \\ 2725 Montlake Blvd. E., Seattle, Washington 98112, USA
}

\begin{abstract}
Hydropic vacuolation (HydVac) of biliary epithelial cells and hepatocytes is described for 3 species of U.S. West Coast bottom fishes. Risk assessment analyses are also conducted to determine if the prevalence of this lesion increases in assocration with contaminant exposure and site of capture. The morphology of HydVac in starry flounder Platichthys stellatus, white croaker Genyonemus lineatus and rock sole Lepidopsetta bilineata was similar to that described in winter flounder Pleuronectes americanus from the U.S. Atlantic Coast, especially in that HydVac most commonly affected biliary epithelial cells. Hydropic vacuolation was the most prevalent liver lesion in starry flounder and white croaker captured from contaminated environments. Risk assessment analyses confirmed that the relative risk for HydVac increased with the presence of aromatic and chlorinated hydrocarbons in sediment, fish bile, and fish liver for these species. Hydropic vacuolation also frequently occurred in rock sole, but the lesion showed no clear association with contaminant exposure in this species. The types of liver lesions that were useful biomarkers of contaminant effects in fish depended on the species and this factor must be taken into account when evaluating histopathological biomarkers of response to contaminant exposure.
\end{abstract}

KEY WORDS: Fish · Contaminants - Liver disease - Hydropic vacuolation - Biomarkers - Risk assessment

\section{INTRODUCTION}

Several liver lesions in certain species of marine fish have been shown to be associated with exposure to xenobiotic chemicals (Myers et al. 1990, 1994, Moore 1991, Johnson et al. 1992, Moore \& Myers 1994, Moore \& Stegeman 1994, Moore et al. 1996). These liver lesions, including neoplasms, foci of cellular alteration, other non-neoplastic proliferative lesions and specific degenerative/necrotic lesions, are well established as histological biomarkers of response to contaminant exposure (Moore 1991, Johnson et al. 1992, Moore \& Myers 1994, Myers et al. 1994). Another hepatic lesion, hydropic vacuolation (HydVac) of biliary epithelial cells and hepatocytes, has been described in detail for

•E-mail: carla.m.stehr@noaa.gov winter flounder Pleuronectes americanus from the U.S. Atlantic Coast (Murchelano \& Wolke 1985, Moore et al. 1989, Bodammer \& Murchelano 1990, Moore 1991) and has been shown to be strongly associated with contaminant exposure in this species. Hydropic vacuolation in winter flounder is particularly prevalent in urban and industrialized areas near Boston and New York where chemical contaminant levels are high in the marine environment (Gardner et al. 1989, Moore 1991, Johnson et al. 1992, 1993, Augspurger et al. 1994, Moore \& Stegeman 1994, Moore et al. 1996).

HydVac-like lesions are now being observed in other species, including white perch Morone americana (Camus \& Wolke 1991) from the U.S. Atlantic Coast and flounder Platichthys flesus from Dutch coastal and estuarine waters (Vethaak \& Wester 1996). In addition, we have identified HydVac in 3 other species 
of marine fish from the U.S. West Coast including starry flounder Platichthys stellatus, white croaker Genyonemus lineatus, and rock sole Lepidopsetta bilineata (Stehr 1990, Stehr et al. 1991, Myers et al. 1994, Myers et al. 1998).

Starry flounder and rock sole are pleuronectids that live in close association with bottom sediments and eat benthic organisms such as worms and clams, and are abundant from Alaska to Northern California (Orcutt 1950, Horton 1989). White croaker is a sciaenid that is abundant in nearshore waters along California's coast. White croaker resides in the water column close to the bottom and is generally a benthic feeder (Love et al. 1984). There is little information about migratory patterns for these species, although flatfish are thought to migrate to local spawning grounds for a few weeks each year. All 3 species inhabit urban or industrialized bays and estuaries where contaminants are likely to occur, and are considered useful sentinel organisms for monitoring the health of the marine environment (Myers et al. 1994)

Previously, winter flounder from the U.S. Atlantic Coast was the only species with a complete histological and ultrastructural description of HydVac (Murchelano \& Wolke 1985, Moore et al. 1989, Bodammer \& Murchelano 1990, Moore 1991). This paper describes the histology and ultrastructure of HydVac for 3 additional fish species. Data subsets from several published and unpublished studies are combined and the prevalence of HydVac is assessed for each of these species. These large data sets are also analyzed by risk assessment techniques, providing new information about relationships between the occurrence of HydVac and contaminant exposure. This paper provides sufficient information for species comparisons, and reports for the first time that species differences occur with regard to association of this lesion with contaminant exposure, and how frequently HydVac is associated with neoplasms. Species-specific considerations for using this lesion as a biomarker of response to contaminant exposure are discussed.

\section{MATERIALS AND METHODS}

Data from unpublished and previously published studies conducted by our laboratory over the last $15 \mathrm{yr}$ within Puget Sound (Washington, USA) and along the U.S. West Coast are combined in the present paper to examine the occurrence of HydVac in 3 West Coast fish species. Starry flounder and white croaker data are from a long-term monitoring study conducted along the coastlines of the USA [National Benthic Surveillance Project (NBSP) of the National Status and Trends Program], including West Coast NBSP data collected from 1984 to 1988 (Myers et al. 1994); San Francisco Bay NBSP data from 1984 to 1991 (Stehr et al. 1997), and previously unpublished West Coast NBSP data collected from 1989 to 1991. About twothirds of the rock sole liver lesion data are from the Marine Ecosystems Analysis (MESA) Puget Sound Project conducted in the 1980s. Sediment chemistry data for this project have been published (Malins et al. 1982, 1984); however the present paper reports the rock sole liver lesion data for the first time. The remaining rock sole data (Myers et al. 1995, Collier et al. 1997, Johnson et al. 1998, Myers et al. 1998, Johnson unpubl.) and sub-adult starry flounder data (Myers et al. 1992, Myers et al. 1995, Myers et al. 1998, Myers unpubl.) are from various field studies in Puget Sound.

Sample collection and chemical analyses. Tissue collection from NBSP studies of starry flounder and white croaker, collection of sediment at areas where these species were captured, and processing and analyses of histological and chemical samples are described in detail by Myers et al. (1994). Collection methods for rock sole tissues and sediment from Puget Sound studies were generally similar to the NBSP methods. Starry flounder and white croaker were collected by bottom trawl from several areas along the U.S. Pacific Coast (Fig. 1). Rock sole were collected in a similar manner from a number of sites within Puget Sound (Fig. 2). Reproductively mature fish were the target size examined for most of the projects reported in this paper. However, juvenile fish were sometimes more abundant than adults at certain sites, so these may have been sampled as well. All sizes of fish were included in the risk assessment studies reported in this paper, with the exception of the sub-adult starry flounder risk assessment for Puget Sound sites, where reproductively immature, juvenile fish up to 4 yr of age were analyzed. Fish were kept alive in fresh flowing seawater for no more than a few hours until necropsies could be performed on the research vessel. Fish were weighed $(\mathrm{g})$, measured (total length in $\mathrm{mm}$ ), killed by severing the spinal column, and immediately necropsied. Otoliths were collected for age determination.

Bile was collected in amber-colored vials, frozen at $-20^{\circ} \mathrm{C}$ and later analyzed for fluorescent aromatic hydrocarbons (FACs) using high-performance liquid chromatography (HPLC) with UV-fluorescence detection according to Krahn et al. $(1986,1987)$ as an estimate of recent polycyclic aromatic hydrocarbon (PAH) exposure. The excitation/emission wavelengths used were $290 / 335 \mathrm{~nm}$ for low molecular weight FACs such as naphthalene and structurally similar compounds, and $380 / 430 \mathrm{~nm}$ for high molecular weight FACs such as benzo[a]pyrene and structurally similar compounds.

Liver was divided for histology and organic chemical analyses. Histology samples were collected first to 
avoid autolysis of tissues. Midsagittal portions of liver were excised and immediately preserved in Dietrich's fixative for light microscopy (Gray 1954). Remaining liver tissue, and stomach contents were placed in separate methylene chloride rinsed vials, frozen at $-20^{\circ} \mathrm{C}$ and later analyzed for chlorinated hydrocarbons using procedures described by Sloan et al. (1993). Analytes measured are listed in the footnotes of Table 2. SmithMcIntyre or Van Veen sediment grabs were used to collect sediment at the sites where fish were caught. A surface layer of sediment about $1 \mathrm{~cm}$ thick was collected. placed in methylene chloride rinsed glass jars, stored frozen at $-20^{\circ} \mathrm{C}$ and analyzed for aromatic and chlorinated hydrocarbons as described by Sloan et al. (1993).

Fewer types of samples were collected for the rock sole studies. Liver histology and sediment analyses for chlorinated and aromatic hydrocarbons conducted during the MESA Puget Sound Project (Malins et al. 1982 , 1984) used methods similar to those described above for starry flounder and white croaker. However the presence of chemical contaminants in rock sole liver was not determined. In the more recent rock sole studies (Collier et al. 1997, Johnson et al. 1998, Myers

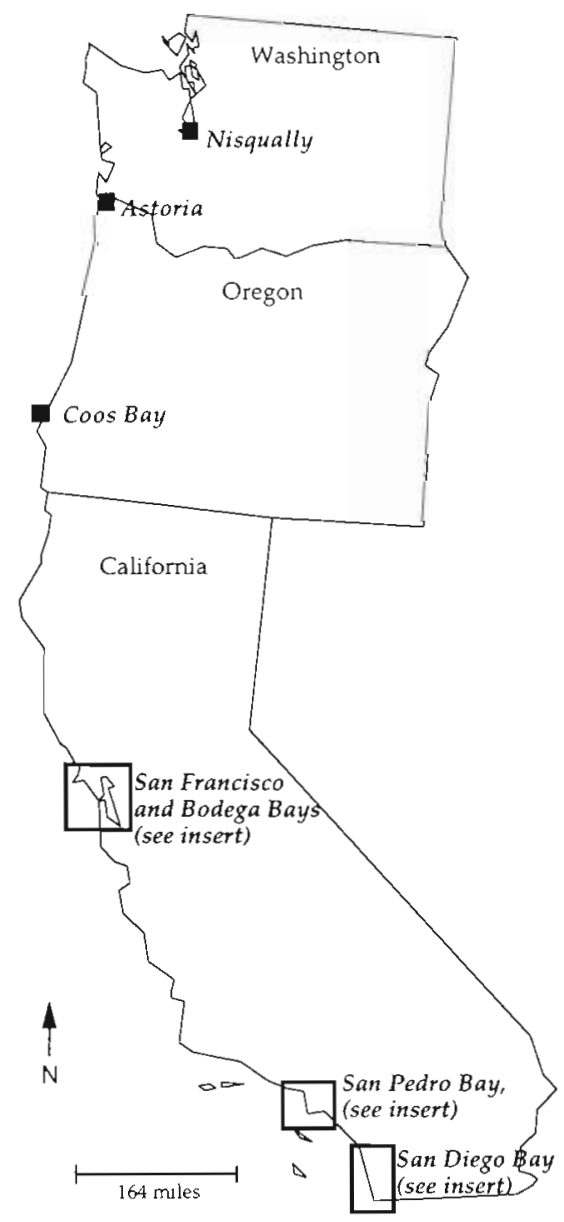

et al. 1998, Johnson unpubl.), rock sole livers were examined histologically and bile was analyzed for FACs as described above. Livers from some of these fish were also analyzed for chlorinated hydrocarbons (Collier et al. 1997, Johnson et al. 1998).

Tissue processing for light and electron microscopy. Tissue sections fixed in Dietrich's solution were embedded in paraffin, sectioned, stained with hematoxylin and eosin (H\&E) (Luna 1968) and examined for the presence of liver lesions. With light microscopy it can be difficult to distinguish small sinusoids from a single biliary epithelial cell affected by hydropic vacuolation; therefore this lesion was diagnosed when at least 3 vacuolated cells with eccentrically located nuclei were grouped in ductular-like patterns, and at least 3 or more groups of vacuolated cells were observed in a tissue section.

In a subset of samples (approximately 15 to 30 of each species), small pieces of tissue adjacent to the light microscopy sample were collected for electron microscopy and fixed for 12 to $24 \mathrm{~h}$ in $0.75 \% \mathrm{glu}$ taraldehyde, $2 \%$ formalin in a $0.1 \mathrm{M}$ sodium cacodylic buffer ( $\mathrm{pH} 7.4$ ). Tissues were rinsed in buffer, postfixed in $2 \%$ osmium tetroxide for $1.5 \mathrm{~h}$, dehydrated in ethanol, and embedded in Spurr's plastic. Semi-thin plastic sections $(1 \mu \mathrm{m})$ were stained with Azure II/ Methylene Blue and examined with light microscopy for the presence of hydropic vacuolation. Thin sections $(80 \mathrm{~nm})$ were cut and stained with uranyl acetate and lead citrate and examined with transmission electron microscopy.
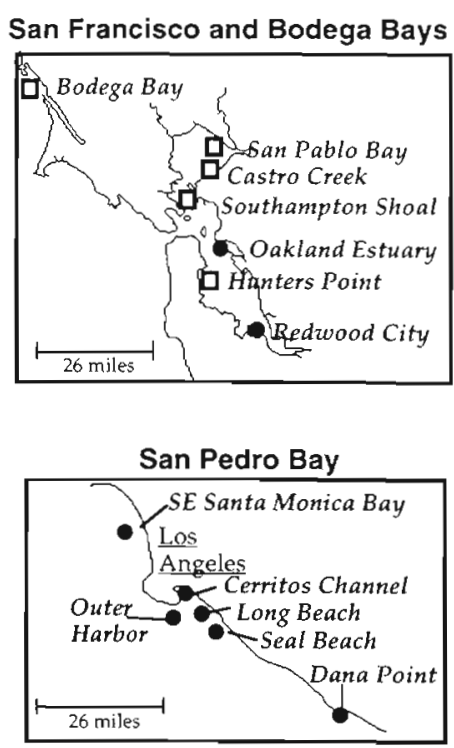

= sampling sites for white croaker = sampling sites for starry flounder $\boldsymbol{\square}$ = sampling sites for both white croaker and starry flounder

Fig. 1. Map of U.S. West Coast sites for collection of starry flounder and white croaker 


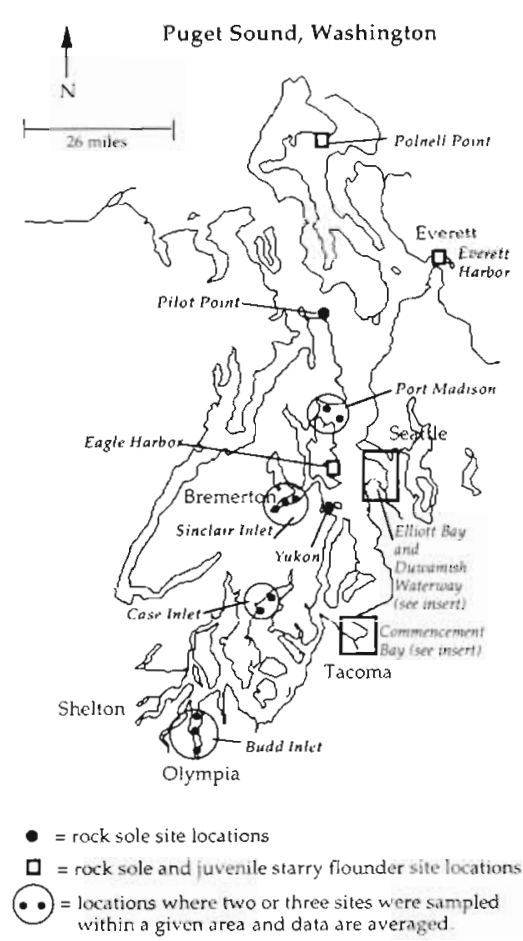

Fig. 2. Map of Puget Sound sites for collection of rock sole
Elliott Bay and Duwamish Waterway
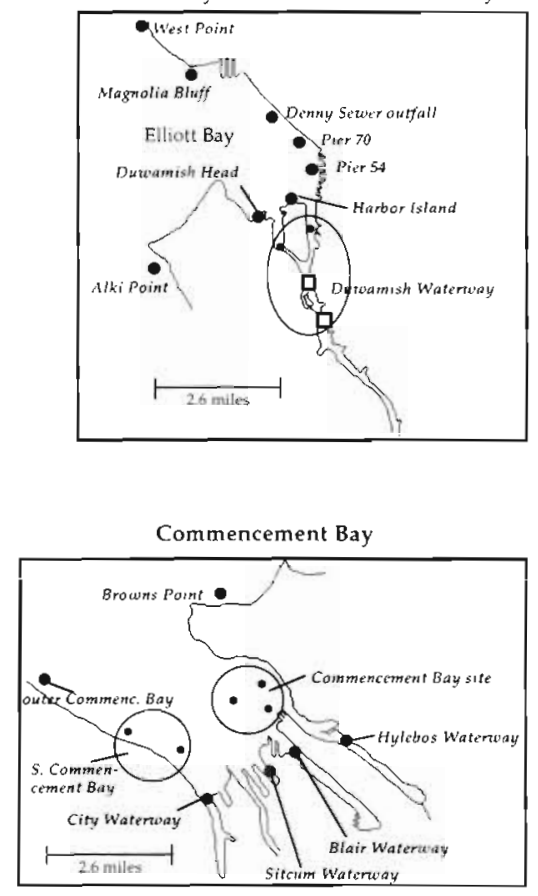

by Myers et al. (1994). Briefly, stepwise logistic regression was used to determine if there was a statistical associdtion between the frequency of HydVac and the site of capture, or with concentrations of specific types of contaminants (chemical risk factors) in sediment and fish tissues, while accounting for fish age and sex, using a critical significance level of $p \leq 0.05$. A number of chemical contaminants were measured in this study, so it would have been desirable to evaluate their relative importance as risk factors for HydVac using multifactor logistic regression to test all of the risk factors within the same statistical model. However, several of the chemical risk factors were highly correlated. Therefore associations between chemical risk factors and lesion prevalences were examined separately while adjusting for potential effects of mean fish age for each sampling site.
Age determination. Age for about one-third of the starry flounder, white croaker and rock sole was determined by direct examination of otoliths, and the remaining ages were estimated from age-length curves generated by simple or polynomial regression. Equations to estimate age were generated for each specific geographical area, and for each sex where sufficient otolith-derived age data were available. Equations used to estimate ages of starry flounder and white croaker for several geographic regions along the U.S. Pacific Coast are listed in Myers et al. (1993). Equations used to estimate ages for rock sole from Puget Sound were age $=-3.593+0.037$ length for males, and age $=-3.432+0.036$ length for females

Statistical methods. Statistical methods used to examine associations between contaminants and the occurrence of HydVac were similar to those described

\section{RESULTS AND DISCUSSION}

\section{Description of hydropic vacuolation}

\section{Microscopy}

HydVac in all 3 West Coast species (Figs. 3 to 14) appeared to be morphologically similar to the same lesion described for winter flounder (Murchelano \& Wolke 1985, Bodammer \& Murchelano 1990, Moore 1991). Hydropic vacuolation was generally apparent with light microscopy as a single large, hydropicappearing vacuole that almost completely filled each affected cell, with little cytoplasm remaining (Figs. 3 to 9). The edges of the vacuoles were smooth, as if they were membrane bound, and the vacuoles appeared to be empty. They did not stain with either H\&E stain

Figs. 3 to 8. Light microscopy (LM) of hydropic vacuolation (HydVac) in liver of Platichthys stellatus, Lepidopsetta bilineata and Genyonemus lineatus. Fig. 3. Mild case of HydVac in starry flounder showing eccentrically located nuclei (small arrows). Cells affected by HydVac sometimes appear to be in the center of hepatic tubules (large arrows), ×400. Fig. 4. Mild case of HydVac in starry flounder liver. Affected cells (arrows) can be distinguished from the other hepatocytes in this micrograph that have a flocculent-like, 'vacuolated' appearance (arrowheads) indicative of abundant lipid and glycogen. $\times 400$. Fig. 5. Moderate to severe case of HydVac in the liver of rock sole. Groups of vacuolated cells are organized to suggest that large portions of bile ductules, ducts, or hepatic tubules may be affected (arrows). $\times 400$. Fig. 6 . HydVac (arrows) intermingled with cells of a cholangiocellular carcinoma $(\mathrm{CC})$ in the liver of rock sole. $\times 200$. Fig. 7 . Moderate case of HydVac (arrows) in the liver of white croaker. $\times 400$. Fig. 8. Rare case of focal HydVac (fHV) in white croaker. The focus is nearly completely composed of hydropically vacuolated cells, while outside the focus, HydVac is more diffusely distributed throughout the rest of the liver. $\times 200$ 


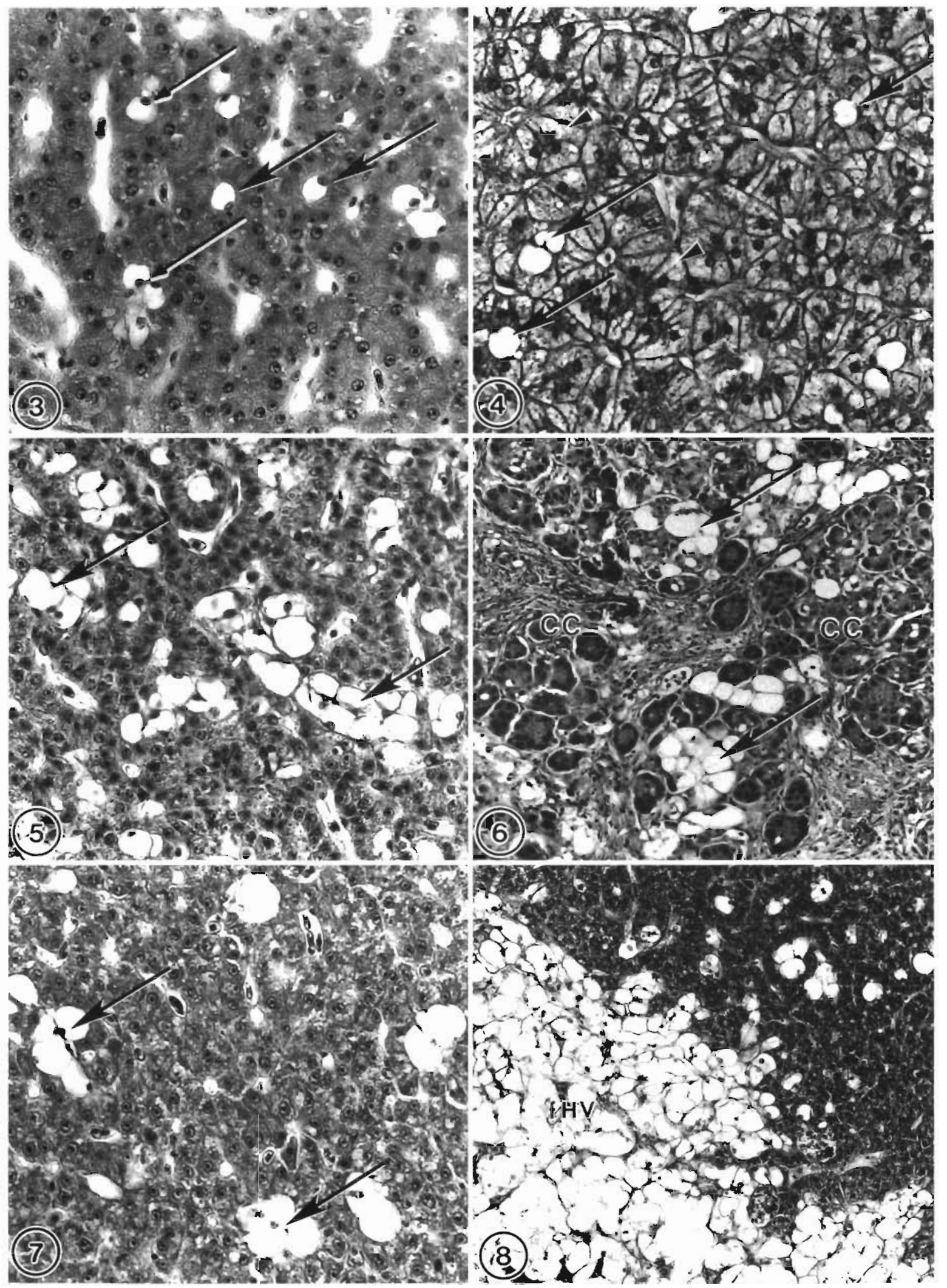




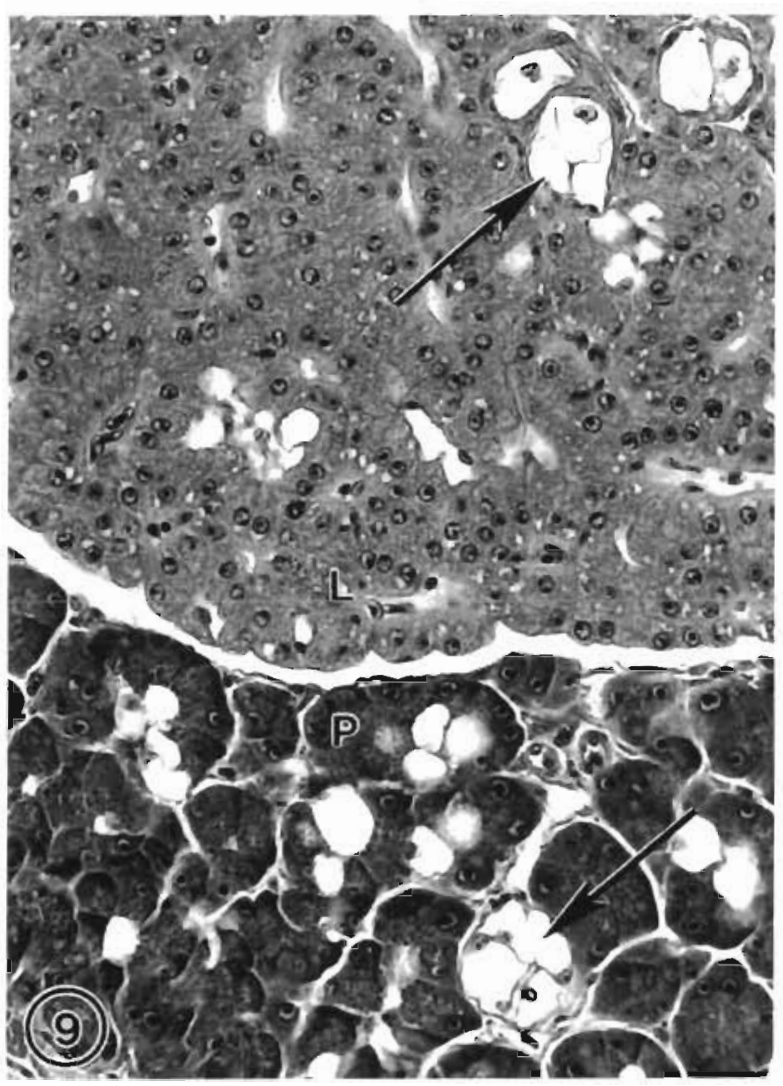

Fig. 9. Platichthys stellatus. LM of moderate case of HydVac (arrows) in the liver $(\mathrm{L})$ and pancreas $(\mathrm{P})$ of starry flounder. $\times 400$

(Figs. 3 to 9), or Periodic Acid-Schiffs reagent (not shown) for glycogen. With careful observation, cells affected by HydVac could be distinguished by light microscopy from the 'vacuolated' appearance sometimes attributed to the presence of abundant glycogen and lipid in hepatocytes (Fig. 4). Although lipid droplets and glycogen are not contained within vacuoles, their presence (or remnants, if they have washed out of the section) often resemble an accumulation of small 'vacuoles', resulting in a more flocculent appearance of the cytoplasm, compared to the single large emptyappearing vacuole of cells affected by HydVac (Fig. 4).

Electron microscopy showed that the vacuoles appeared to be an extreme dilation of the perinuclear space (Figs. 10 to 14), and the vacuoles were bordered by rough endoplasmic reticulum (RER) (Fig. 12). Sparsely distributed flocculent or vesicular-like materials were occasionally observed in these nearly emptyappearing vacuoles. These features clearly distinguish HydVac vacuoles from typical lipid (Fig. 10) and glycogen inclusions.

Dilation of the perinuclear space has occasionally been observed in other cell types of higher vertebrates in response to certain chemical exposures. Examples include gall bladder epithelium in rabbit exposed to 6-aminonicotinamide, which is a drug used to treat psoriasis (Render \& Carlton 1985), pancreatic acinar cells in rat exposed to lead acetate (Andrzejewska et al. 1995) and human lymphocytes in vitro, human keratinocytes in culture and the skin of the hairless guinea pig exposed to sulfur mustard (Petrali et al. 1990a, b). Perinuclear space dilation has also been described in human hepatocytes infected with viral hepatitis (Phillips et al. 1987). However, the perinuclear space dilations or blebbings observed in these studies were generally much smaller compared to that in the fish of the present study, and frequently accompanied by other necrotic subcellular changes. It is not clear what mechanism(s) might contribute to the formation of a dilated perinuclear space, although impaired ion/water control is believed to play a role (Render \& Carlton 1985, Phillips et al. 1987) and DNA damage leading to enhancement of protease synthesis and release is believed to play a role in subcellular changes seen in sulfur mustard exposed cell types (Papirmeister et al. 1985, Petrali et al. 1990a, b).

Both light and electron microscopy indicated that the nucleus was eccentrically located within the vacuole. In the majority of cells affected by HydVac, the nucleus appeared elongated or elliptical and morphologically similar to the nucleus of BECs. However, round nuclei that appeared more like that of hepatocytes were also occasionally observed in affected cells, especially in starry flounder (Fig. 14)

Since scant cytoplasm remained in affected cells, identification of cell type was based on location in relation to other cell types. Cells affected by HydVac appeared to be located in positions typical of both BECs and hepatocytes. For example, in normal liver, desmosomes occur between hepatocytes only near the bile canaliculi. Desmosomes also occur between preductular BECs and hepatocytes, or between adjacent preductular BECs. Desmosomes located close to bile canaliculi were frequent between cells affected by HydVac and neighboring cells (Fig. 11). The majority of the cells affected appeared to be BECs, as most were organized in ductular formations, or contained within clearly defined bile ducts (Figs. 5 \& 13). Occasionally, affected cells resembled hepatocytes, as they were located adjacent to sinusoids, and had a more spherical nucleus (Fig, 14). In addition, smaller vacuoles often lined by RER were also observed in some cells affected with HydVac (Fig. 14), particularly in cells that appeared to be hepatocytes. Since the RER that forms the border of the perinuclear space is continuous with the RER throughout the rest of the cell, it's likely that the cisternae of RER may also be dilated. Smaller vacuoles or dilated portions of the RER would likely occur more frequently in hepatocytes since the RER is considerably more abundant in hepatocytes compared to BECs. 

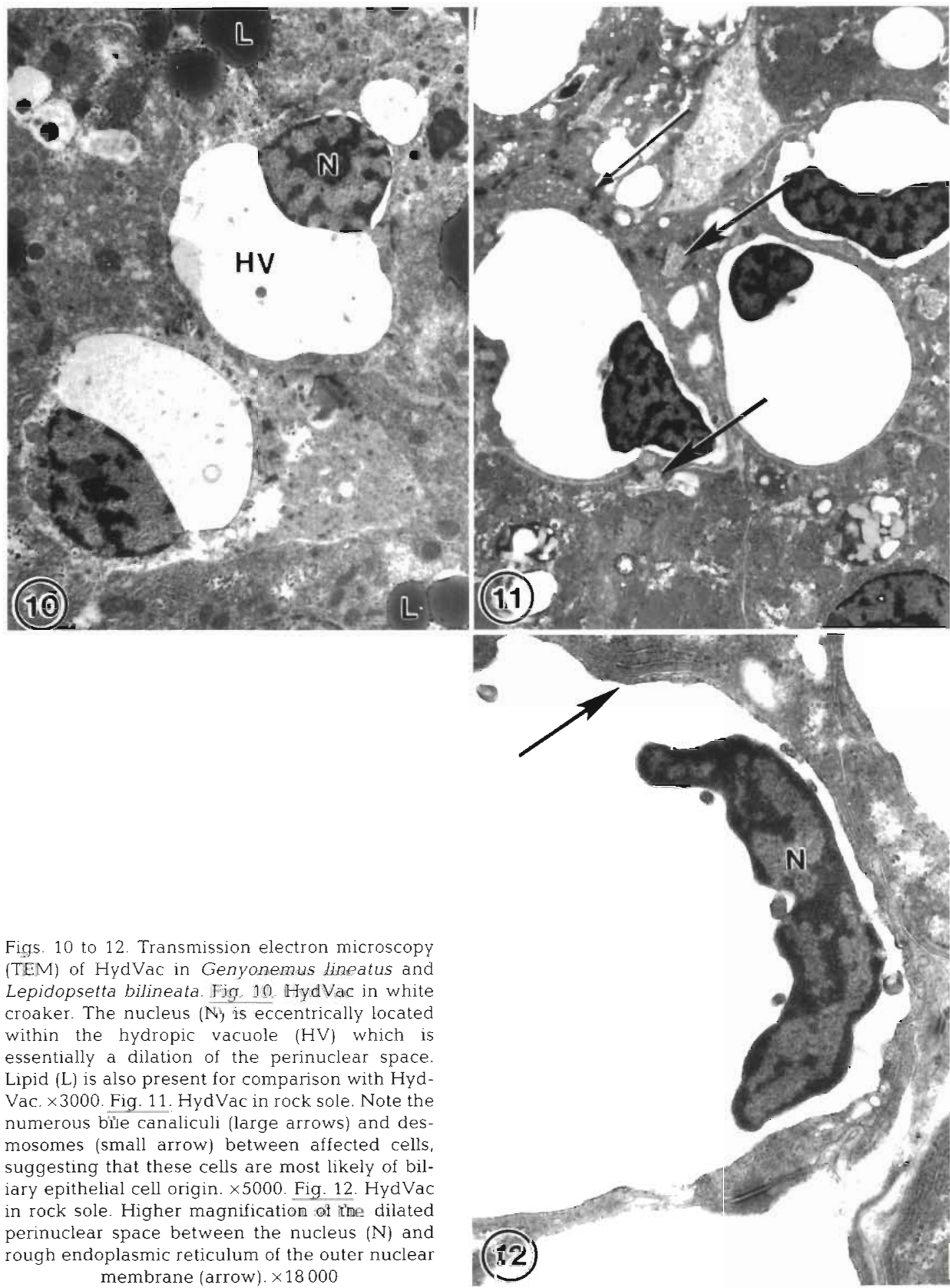

Figs. 10 to 12. Transmission electron microscopy (TEM) of HydVac in Genyonemus lineatus and Lepidopsetta bilineata. Fig. 10. HydVac in white croaker. The nucleus $(\mathrm{N})$ is eccentrically located within the hydropic vacuole (HV) which is essentially a dilation of the perinuclear space. Lipid $(\mathrm{L})$ is also present for comparison with HydVac. $\times 3000$. Fig. 11. HydVac in rock sole. Note the numerous bile canaliculi (large arrows) and desmosomes (small arrow) between affected cells, suggesting that these cells are most likely of biliary epithelial cell origin. $\times 5000$. Fig. 12 . HydVac in rock sole. Higher magnification of the dilated perinuclear space between the nucleus $(N)$ and rough endoplasmic reticulum of the outer nuclear membrane (arrow) $\times 18000$

In mild cases, single cells and small groups of 2 to 3 cells affected by HydVac were diffusely distributed throughout the liver (Figs. $3 \& 4$ ). Affected cells were often located in the center of hepatic tubules, suggesting that they could be either hepatocytes or preductu- lar BECs. Most likely these were preductular BECs, as the progression of the lesion in West Coast species appeared similar to that described for winter flounder, where centro-tubular, preductular BECs are first affected (Moore et al. 1989, Moore 1991). In more severe 

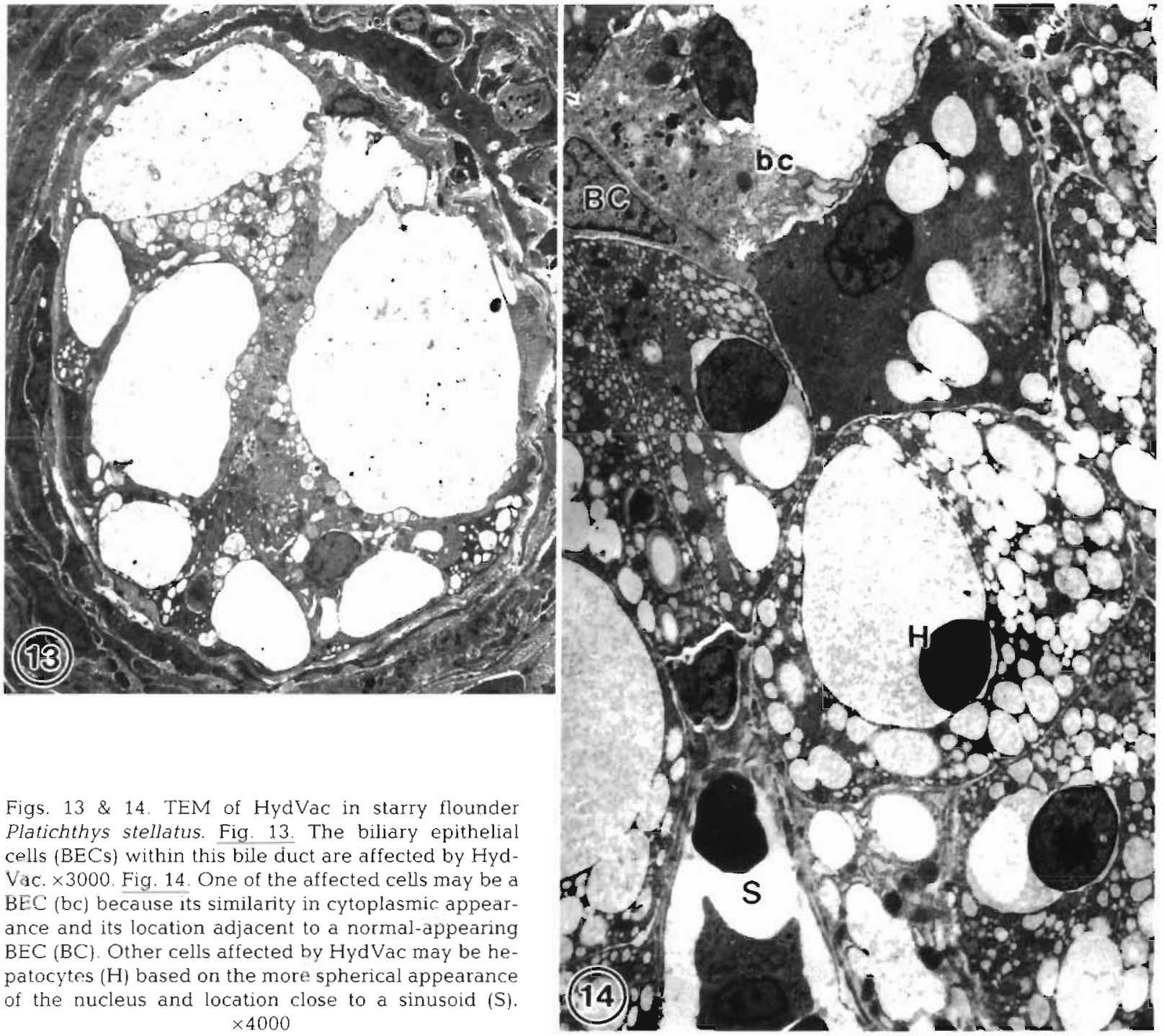

Figs. 13 \& 14. TEM of HydVac in starry flounder Platichthys stellatus. Fig. 13. The biliary epithelial cells (BECS) within this bile duct are affected by HydVac. $\times 3000$. Fig. 14. One of the affected cells may be a $\mathrm{BEC}(\mathrm{bc}$ ) because its similarity in cytoplasmic appearance and its location adjacent to a normal-appearing BEC (BC). Other cells affected by HydVac may be hepatocytes $(\mathrm{H})$ based on the more spherical appearance of the nucleus and location close to a sinusoid (S). $\times 4000$

\section{Proliferative characteristics and association with neoplasms}

cases of HydVac, BECs located within entire portions of ductules or ducts were affected (Figs. 5, $9 \& 13$ ), as well as cells that sometimes appeared to be hepatocytes (Fig. 14). In addition, HydVac in the liver was infrequently accompanied by HydVac of exocrine pancreatic cells (Fig. 9)

A focal form of HydVac was also occasionally observed in white croaker and rock sole, where nearly all of the cells within a specific area or 'focus' were affected (Fig. 8). The focal form of HydVac in particular has been observed in close association with neoplasms in the liver of winter flounder (Moore \& Stegeman 1994). However, only the diffuse form of HydVac was observed within neoplasms in the 1 or 2 cases where HydVac was closely associated with neoplasms in rock sole (Fig. 6) and white croaker
The morphology of HydVac in West Coast fish does not clearly indicate whether there is a degenerative or proliferative mechanism of lesion pathogenesis, or both. Although pyknotic nuclei were occasionally observed, affected cells did not generally appear necrotic. In fact, most nuclei appeared quite functional, as did the cytoplasm even though little cytoplasm remained. Contrary to observations in winter flounder by Bodammer \& Murchelano (1990), we saw no evidence that this lesion represented apoptosis of any cell type. Mitotic figures were also not observed in hydropically vacuolated cells; however, HydVac in white croaker was observed in 1 or 2 cases to be spatially associated with proliferative liver lesions such as oval 


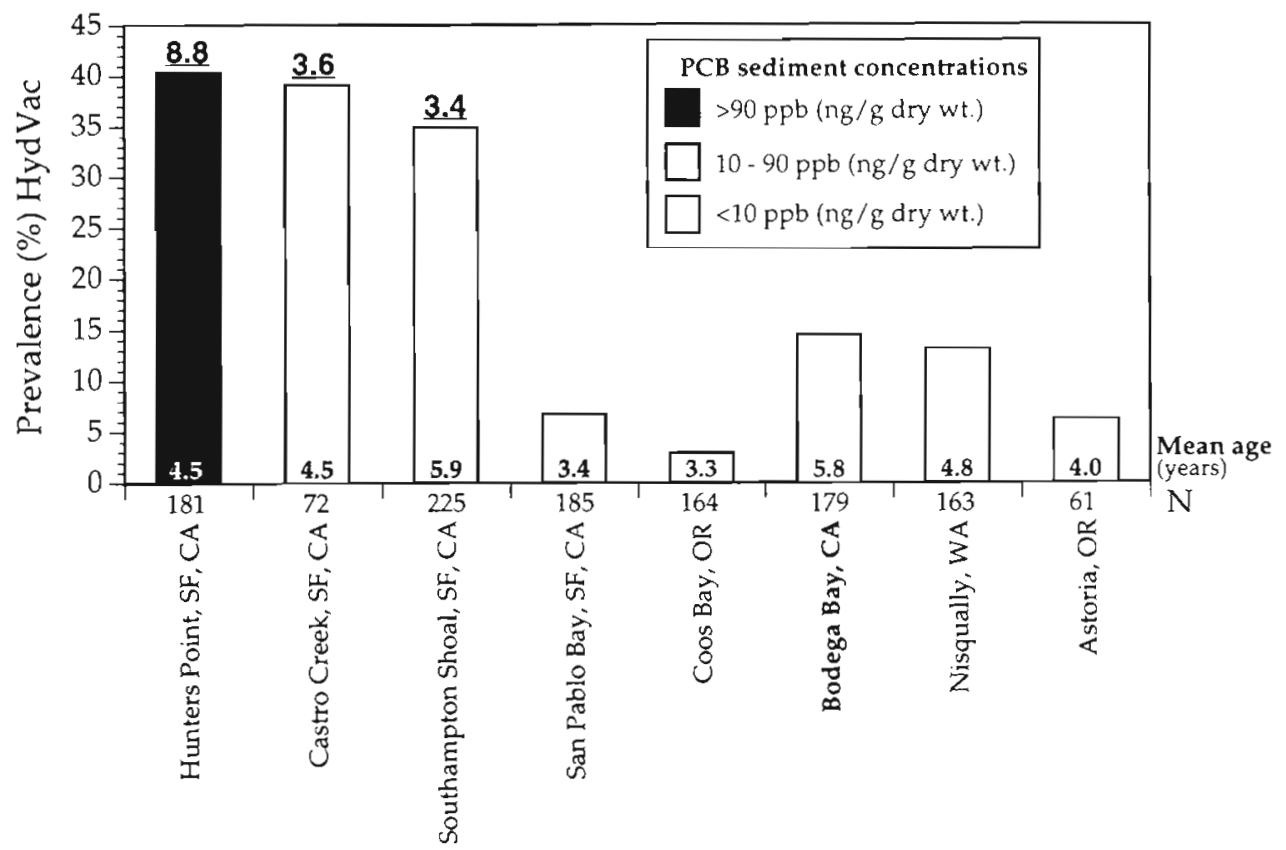

Fig. 15. Platichthys stellatus. Prevalence of HydVac in starry flounder from U.S. West Coast sites. Underlined numbers are the odds ratios for sites where fish had a significantly higher risk of having HydVac compared to the Bodega Bay reference site (in bold) after age was accounted for as determined by logistic regression $(p<0.05)$. For instance, the odds ratio for Hunters Point, San Francisco Bay, indicates that starry flounder from this site had an 8.8 times greater chance of having HydVac compared to flounder of the same age at the Bodega Bay reference site. Sites are shown from left to right in order of decreasing concentrations of $\Sigma$ PCBs in sediment. SF: San Francisco Bay; CA: California; OR: Oregon; WA: Washington. N: number of fish examined at each site

cell proliferation, hepatocellular regeneration or biliary proliferation.

The proliferative capacity of hydropically vacuolated cells in winter flounder has been studied by analyzing ornithine decarboxylase activity (Koza et al. 1993) and bromodeoxyuridine labeling indices (Moore \& Stegeman 1994). Results led the authors to conclude that hydropically vacuolated cells in winter flounder were capable of replicative synthesis of DNA, and they postulated that affected cells have the potential to proliferate and may be involved in the histogenesis of cholangiocellular neoplasms in winter flounder. However, preliminary work by our laboratory with proliferating cell nuclear antigen (PCNA) has not shown labeling of HydVac cells in starry flounder, white croaker or rock sole, although biliary epithelial cells and hepatocytes adjacent to HydVac cells often showed PCNA labeling (M. J. Willis unpubl. data).

In winter flounder, HydVac was nearly always associated with neoplasms, particularly cholangiocellular carcinomas (Murchelano \& Wolke 1985, Gardner et al. 1989, Moore 1991, Moore \& Stegeman 1994). Neoplasms in winter flounder were either contained within focal forms of HydVac, or the neoplasms themselves contained or were fringed by the diffuse form of

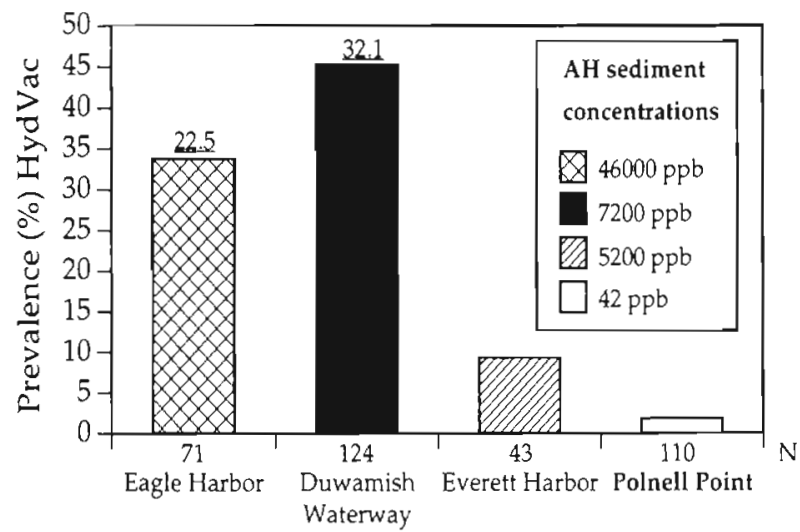

Fig. 16. Platichthys stellatus. Prevalence of HydVac in subadult ( 0 to 4 yr) starry flounder from Puget Sound. Underlined numbers are the odds ratios at sites where fish had a significantly higher risk of developing HydVac compared to the Polnell Point reference site (in bold) after age was accounted for with logistic regression $(p<0.05)$. For instance, juvenile starry flounder at Duwamish Waterway had a 32.1 times greater chance of having HydVac compared to flounder of the same age at the Polnell Point reference site. Lesion data is from Myers et al. (1997) and Myers unpubl. Sites are listed from left to right in order of decreasing sediment concentrations of total aromatic hydrocarbons (A.Hs). Sediment data for Eagle Harbor is from Malins et al. (1985); sediment data for the remaining sites is from Stein et al. (1992). N: number of fish examined at each site 


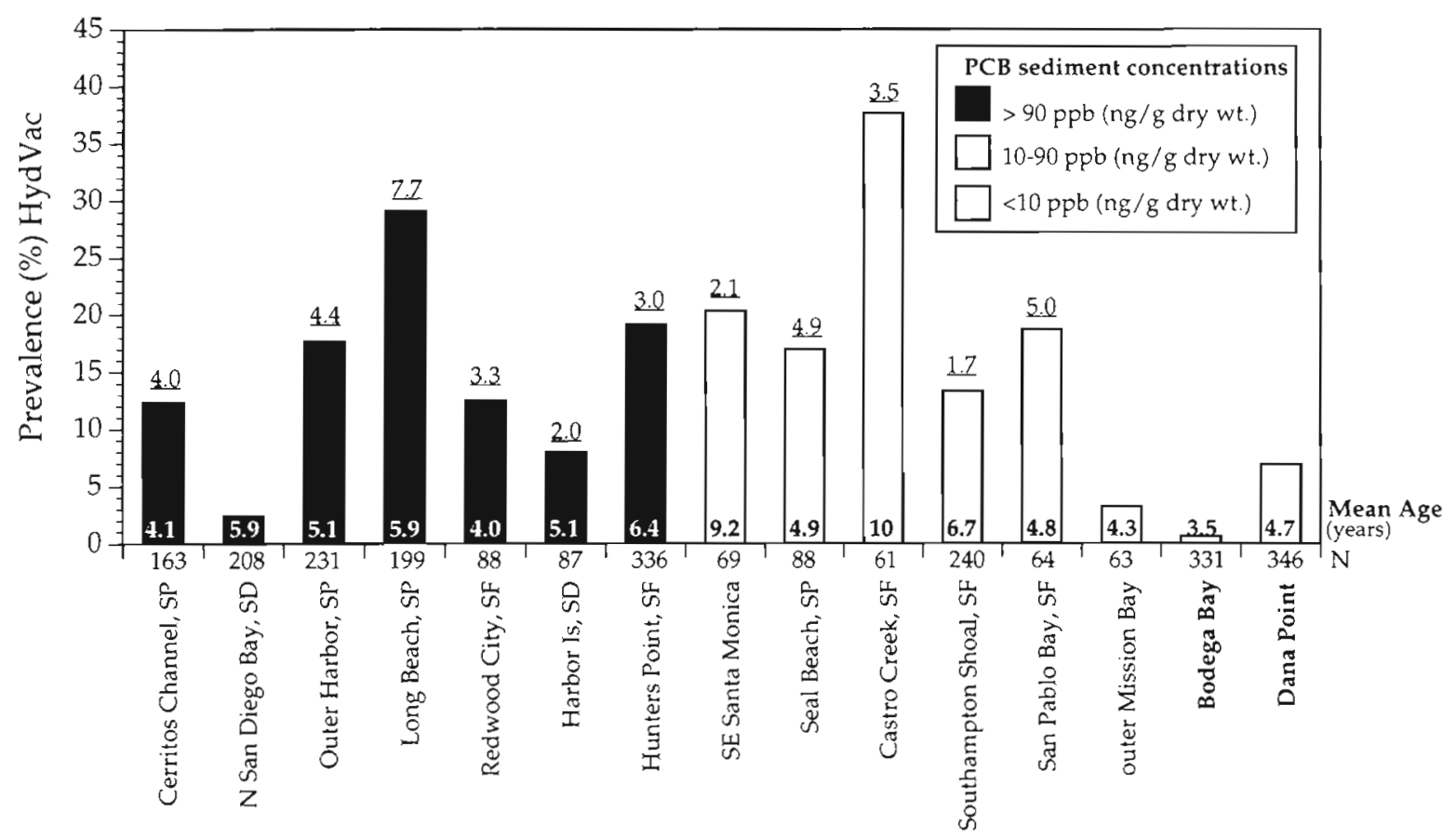

Fig. 17. Genyonemus lineatus. Prevalence of HydVac for white croaker from U.S. West Coast sites. Underlined numbers are the odds ratios at sites where fish had a significantly greater chance of having HydVac compared to the Bodega Bay reference site, after age and sex were accounted for, as determined by logistic regression $(p<0.05)$. For instance, white croaker at Long Beach had a 7.7 times greater chance of having HydVac compared to croaker of the same age at the Bodega Bay and Dana Point reference sites. Sites are shown from left to right in order of decreasing concentrations of $\sum$ PCBs in sediment. All sites are located in

California. SP: San Pablo Bay; SD: San Diego Bay; SF: San Francisco Bay. N: number of tish examined at each site

HydVac (Moore \& Stegeman 1994). The association of HydVac with neoplasms for white croaker and rock sole was observed in only 1 or 2 cases, and no neoplasms were observed in starry flounder. However, neoplasms in general were observed much less frequently in white croaker and rock sole, and never observed in starry flounder, as summarized in Table 1. If HydVac is associated with the progression of hepatic neoplasia in any of these West Coast fish, this association occurs far less frequently than in winter flounder.

\section{Hydropic vacuolation and associations with contaminant exposure and site of capture}

An epidemiological approach was used to determine if certain classes of chemical contaminants were risk factors for the occurrence of HydVac, and to estimate the relative risk of disease at each site. These analyses were conducted to determine if the presence of HydVac in starry flounder, white croaker and rock sole was associated with contaminant exposure, and to see if this lesion was a practical histological biomarker of response to contaminant exposure.

\section{Sex and age associations with hydropic vacuolation}

Several types of contaminant-related liver lesions, such as neoplasms and preneoplastic focal lesions, occur more frequently in fish as they become older, independent of any environmental influences (Myers et al. 1987, 1994). In addition, a few types of liver lesions may occur more frequently in one sex compared to the ather, independent of other factors (Myers et al. 1987, 1994). Therefore, age and sex of starry flounder, white croaker and rock sole were included in the stepwise logistic regression analyses for risk assessment of HydVac. Results showed that the sex of the animal did not increase the risk of HydVac for any of the species. In contrast, for each year of age, the risk of HydVac increased 1.3 times in starry flounder or white croaker, and 1.4 times in rock sole.

\section{Chemical concentrations and HydVac}

Starry flounder and white croaker. Chlorinated $(\mathrm{CH})$ and aromatic hydrocarbon (AH) concentrations in liver, bile and sediment were tested by stepwise logistic regression to determine if the presence of these 

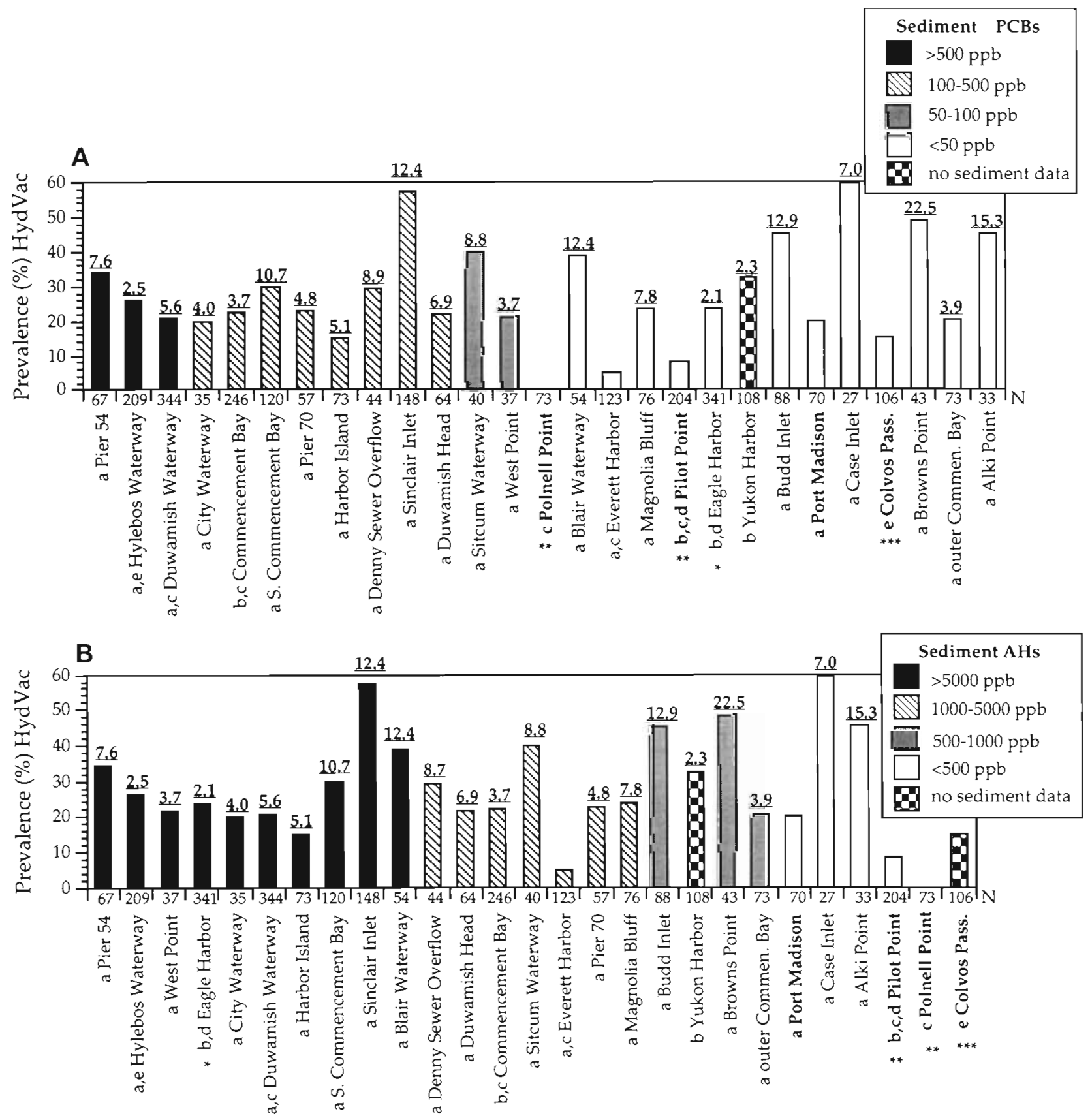

Fig. 18. Lepidopsetta bilineata. Prevalence of HydVac in rock sole from Puget Sound, sites listed in decreasing order of sediment concentrations for (A) sum of PCBs and (B) sum of total AHs. Units of measure are ng $\mathrm{g}^{-1}$ (ppb) dry weight. Reference sites are indicated in bold. Underlined numbers are odds ratios for sites with increased risk of HydVac compared to the reference sites. For instance, rock sole at Sinclair Inlet had a 12.4 times greater chance of having HydVac compared to rock sole of the same age at the reference sites. N: number of fish examined. HydVac prevalence data are from: a, Myers unpubl.; b, Johnson et al. (1998); c) Myers et al. (1992); and d, Collier et al. (1997). Sediment chemical concentration data is from: "Malins et al. (1985); “'Stein et al. (1992); … Sanborn unpubl.; all others not marked are from Malins et al. (1982). Although no sediment data is available for the Yukon Harbor site, based on biological indicator data (Johnson et al. 1998) this site is considered to be mild to moderately contaminated. Colvos Passage sediment $\mathrm{AH}$ concentrations are not known, but because of its non-urban location, sediment AHs are believed to be comparable with those at the Pilot Point and Polnell Point sites

chemical contaminants increased the risk of HydVac for starry flounder and white croaker from the West Coast sites. Results are summarized in Table 2. In general, CHs appeared to be significant risk factors for
HydVac in white croaker, while low molecular weight bile FACs was the only AH risk factor, and starry flounder showed higher risks of developing HydVac with increasing concentrations of both AHs and CHs. 
Table 1. Association of HydVac with liver neoplasms

\begin{tabular}{|lcccc|}
\hline Species & $\begin{array}{c}\text { No. of } \\
\text { fish examined }\end{array}$ & $\begin{array}{c}\text { No. of fish } \\
\text { with neoplasms }\end{array}$ & $\begin{array}{c}\text { Predominant type } \\
\text { of neoplasm }\end{array}$ & $\begin{array}{c}\% \text { neoplasms assoc. } \\
\text { with HydVac }\end{array}$ \\
\hline Winter flounder Pleuronectes americanus & 293 & 29 & Cholangiocellular & $91 \%$ \\
White croaker Genyonemus lineatus & 2780 & 13 & Cholangiocellular & $15 \%$ \\
Rock sole Lepidopsetta bilineata & 2988 & 26 & Hepatocellular & $4 \%$ \\
Starry flounder Platichthys stallatus & 1273 & 0 & - & - \\
aData from Moore \& Stegeman (1994) & & & & \\
\hline
\end{tabular}

However, the roles that individual chemicals may play in the development of HydVac is not clear. Correlation matrix analyses were done to determine if certain chemical classes tended to co-occur. Correlation matrix analyses for starry flounder showed that liver summed PCBs ( $\sum P C B s$ ) were highly correlated with liver summed DDTs ( $\Sigma D D T s$ ), chlordanes and dieldrin, and associated sediment $\sum$ PCBs were highly correlated with sediment concentrations of low and high molecular weight AHs. In white croaker, although none of the CHs were correlated with the AHs, liver $\sum$ PCBs and chlordanes were highly correlated. Because of the co-occurrence of chemicals in sediment, liver or bile, the information in Table 2 suggests an association between HydVac and exposure but provides only hints about which of the contaminants may play a role in the development of HydVac.
It was surprising that the L-FAC chemical class was the only bile FACs risk factor for HydVac, especially since L-FACs and H-FACs co-occur in the environment, and the benzo[a]pyrene-like compounds in $\mathrm{H}$ FACs are known carcinogens and are associated with development of degenerative, preneoplastic and neoplastic lesions in several fish species (Myers et al. 1994). In contrast, the lower molecular weight hydrocarbons present in L-FACs are not primary carcinogens, but may have cytotoxic or other effects which may promote the development of neoplasms (Williams \& Weisburger 1986). These results suggest that the cytotoxic properties of biliary L-FACs may be more strongly linked to HydVac than the carcinogenic properties of H-FACs. It is interesting to note that both $\mathrm{L}$ FACs and H-FACs have been shown to be risk factors

Table 2. Platichthys stellatus and Genyonemus lineatus. Chemical risk factors for HydVac in starry flounder and white croaker. A chemical class for sediment or fish liver or bile was considered a significant risk factor for HydVac when $p<0.05$, as calculated by logistic regression, after age and sex were taken into account. Units of measure are in $\mathrm{ng} \mathrm{g}^{-1} \mathrm{dry}$ weight

\begin{tabular}{|c|c|c|c|c|c|}
\hline \multicolumn{3}{|c|}{ Starry flounder } & \multicolumn{3}{|c|}{ White croaker } \\
\hline Chemical class & p-value & $N$ & Chemical class & $\mathrm{p}$-value & $\mathrm{N}$ \\
\hline FAC-H bile & ns & 42 & FAC-H bile & ns & 68 \\
\hline FAC-L bile & $p=0.002$ & 42 & FAC-L bile & $p<0.001$ & 68 \\
\hline PCBs-liver & $p<0.001$ & 36 & PCBs-liver & $\mathrm{p}<0.001$ & 52 \\
\hline DDTs-liver & $p=0.001$ & 36 & DDTs-liver & $p<0.001$ & 52 \\
\hline Chlordanes-liver & $p<0.001$ & 36 & Chlordanes-liver & $p<0.001$ & 52 \\
\hline Dieldrin-liver & $\mathrm{p}<0.001$ & 36 & Dieldrin-liver & $\mathrm{p}<0.001$ & 52 \\
\hline LMWAH-sediment & $p<0.001$ & 36 & LMWAH-sediment & ns & 55 \\
\hline HMWAH-sediment & $p<0.001$ & 36 & HMWAH-sediment & ns & 55 \\
\hline PCBs-sediment & $p<0.001$ & 36 & PCBs-sediment & $p=0.002$ & 55 \\
\hline DDTs-sediment & ns & 36 & DDTs-sediment & $p=0.003$ & 55 \\
\hline Chlordanes-sediment & ns & 36 & Chlordanes-sediment & $p<0.001$ & 55 \\
\hline Dieldrin-sediment & $p=0.001$ & 36 & Dieldrin-sediment & ns & 55 \\
\hline \multicolumn{6}{|c|}{ List of analytes and abbreviations } \\
\hline \multicolumn{6}{|c|}{ FAC-H: High molecular weight fluorescent aromatic hydrocarbons (benzo[a|pyrene equivalents) in bile } \\
\hline \multicolumn{6}{|c|}{ FAC-L: Low molecular weight fluorescent aromatic hydrocarbons (naphthalene equivalents) in bile } \\
\hline \multirow{3}{*}{\multicolumn{6}{|c|}{$\begin{array}{l}\text { PCBs: sum of PCBs, including PCB congener numbers } 18,28,44,52,66,101,105,118,128,138,153,170,180,187,195,206,209 \\
\text { DDTs: sum of DDTs including p, } p^{\prime} \text {-DDE, } p, p^{\prime} \text {-DDT, p, p'-DDD } \\
\text { Chlordanes: alpha chlordanes }\end{array}$}} \\
\hline & & & & & \\
\hline & & & & & \\
\hline \multicolumn{6}{|c|}{$\begin{array}{l}\text { LMWAH: low molecular weight aromatic hydrocarbons including naphthalene, acenaphthylene, fluorene, anthracene, } \\
\text { acenaphthene, phenanthrene, } 2 \text {-methylnaphthalene }\end{array}$} \\
\hline \multicolumn{6}{|c|}{$\begin{array}{l}\text { HMWAH: high molecular weight aromatic hydrocarbons including fluoranthene, pyrene, chrysene, benzo[a]pyrene, } \\
\text { dibenz[a }] \text { anthracene, benz[a]anthracene, benzo[b+k]fluoranthenes, ideno[1,2,3-cd|pyrene, benzo[ghi]perylene }\end{array}$} \\
\hline \multicolumn{6}{|c|}{ ns: not significantly different, $p>0.05$} \\
\hline N: number of analyses & $>0.00$ & & f $5-10$ fish & & \\
\hline
\end{tabular}


for HydVac in winter flounder (Johnson et al. 1992, 1993), and as discussed earlier in this paper, HydVac in winter flounder is frequently associated with hepatic neoplasms, whereas HydVac is rarely associated with hepatic neoplasms in croaker and flounder Additional studies are needed to understand the different roles $\mathrm{H}$ FACs and L-FACs may have as risk factors for HydVac, and to see if these roles differ depending on the species affected.

Rock sole. Few tissue chemistry data were available for most of the rock sole studies; therefore evaluation of chemical risk factors for HydVac in rock sole was limited to a few small data sets. Previously unpublished lesion data from the Puget Sound Study conducted between 1979 and 1982 were examined, and risk assessment analyses showed that sediment concentrations of total AHs and $\sum$ PCBs were not risk factors for HydVac in Puget Sound rock sole. In addition, no significant associations were observed between the occurrence of HydVac and chemical exposure indicators such as liver concentrations of $\Sigma P C B$ s, fluorescent aromatic compounds (FACs) in bile, or DNA adducts in liver when rock sole data from 2 recent studies (Myers et al. 1995, Johnson unpubl.) were examined by logistic regression.

\section{Risk of HydVac at each site}

The estimated risk (odds ratio) for the occurrence of HydVac was determined by stepwise logistic regression for each site relative to the reference site(s). Because older fish are more likely to develop HydVac independent of other factors, age was also taken into account in calculation of the odds ratios. Lesion prevalence did not take into account fish age, and fish collected from certain sites tended to be older than fish at other sites. Therefore, odds ratios that are adjusted for age are a better estimate of the association between the occurrence of HydVac and site of capture. The odds ratios shown in Figs. 15 to 18 indicate the probability that HydVac will be present in a fish at a given site relative to the reference site(s) for fish of equivalent age. For instance, the odds ratio for Hunters Point, San Francisco Bay (Fig. 15), indicates that starry flounder from this site had an 8.8 times greater chance of having HydVac compared to flounder of the same age at the Bodega Bay reference site.

Sites are listed from left to right in descending order of sediment $\Sigma$ PCB concentrations in Figs. 15, $17 \& 18 \mathrm{~A}$. Sediment $\Sigma \mathrm{PCB}$ concentration was used as an example to illustrate the relationship between contaminant exposure and HydVac prevalence, because it was one of the most strongly correlated chemical risk factors for both white croaker and starry flounder. Sites are listed in order of decreasing sediment total AH concentrations for Fig. 16, because AH concentrations in sediment were particularly high for this group of sites. Sites are also listed in order of decreasing AH concentrations (Fig. 18B) for rock sole, as an example of associations between concentrations of a different contaminant class and the presence of HydVac in this species. Variations in the ranking of sites between Figs. $18 \mathrm{~A}$ and $18 \mathrm{~B}$ illustrate that contaminant mixtures differ among sites. For instance, Eagle Harbor had high sediment concentrations of AHs and low concentrations of ¿PCBs, while the Duwamish Waterway had high concentrations of both chemical classes (Fig. 18).

Starry flounder. Starry flounder captured at 3 of 8 sites sampled along the U.S. West Coast had significantly higher risks of developing HydVac compared to fish at the Bodega Bay reference site, after fish age was taken into account (Fig. 15). These 3 sites were located within San Francisco Bay, and had the highest concentrations of aromatic and chlorinated hydrocarbons in sediment and liver tissue among the U.S. West Coast sites sampled for starry flounder (Myers et al. 1994. Stehr et al. 1997).

Hydropic vacuolation was the most prevalent type of idiopathic liver lesion observed in starry flounder (Myers et al. 1994. Stehr et al. 1997). This lesion was diagnosed in up to $40 \%$ of starry flounder from certain urban sites sampled in San Francisco Bay between 1984 and 1991, while the second most prevalent type of lesion in starry flounder, specific degenerative/ necrotic lesions (SDN), which include megalocytic hepatosis and nuclear pleomorphism, occurred in 10\% or fewer of the fish (Stehr et al. 1997).

The high prevalences of HydVac, the association of HydVac with several chemical risk factors and with sites that had significantly high concentrations of AHs and $\mathrm{CHs}$, indicates that HydVac is a practical biomarker of contaminant effects for starry flounder

Data from sub-adult ( 0 to 4 yr of age) starry flounder (Myers et al. 1992, 1995, Myers unpubl. data) from selected sites in Puget Sound (Fig 16) showed that young fish captured at the highly contaminated sites of Eagle Harbor and the Duwamish Waterway were 23 and 32 times more likely (respectively) to have FlydVac compared to sub-adult starry flounder from the reference site at Polnell Point, after age was taken into account. A similar association of young fish (2 and 3 yr old) with HydVac and contaminated sites was observed in winter flounder from Jamaica Bay, New York (Augspurger et al. 1994). Therefore, even in young starry flounder and winter flounder the prevalence of HydVac is significantly higher at contaminated sites compared to reference sites.

White croaker. The relative risk of HydVac was significantly higher at 11 of 13 sites sampled along the 
West Coast, compared to the Bodega Bay and Dana Point reference sites after age was taken into account (Fig. 17). Outer Mission Bay had sediment contaminant concentrations similar to those at the reference sites, so no increased risk of HydVac would be expected at that site. It is not clear why North San Diego Bay did not have an increased risk for HydVac given that it had some of the highest levels of sediment PCBs among the white croaker sites. It may be that the fish captured at that site had been in San Diego Bay for only a brief time.

HydVac was the most prevalent lesion observed in white croaker for most sites examined during the NBSP monitoring study (Myers et al. 1994, Stehr et al. 1997). For instance, HydVac occurred in up to $38 \%$ of fish from certain urban sites in San Francisco Bay, compared to a maximum prevalence of $18 \%$ for SDN, which was the second most prevalent contaminantrelated liver lesion for white croaker (Stehr et al. 1997).

The high prevalences of HydVac, the association of HydVac with several chemical risk factors and with sites that had significantly high concentrations of AHs and CHs, indicate that HydVac is also a biomarker of contaminant effects in white croaker.

Rock sole. The prevalence of HydVac in rock sole was determined from the combined data for a number of studies conducted in Puget Sound over the last $15 \mathrm{yr}$ (Fig. 18). About two-thirds of the data used for Fig. 18 were collected between 1979 and 1983, before HydVac was recognized as a potential toxicopathic liver condition in certain species of fish. Liver sections of rock sole from this Puget Sound study were therefore recently re-evaluated for the presence of HydVac.

The prevalence of HydVac and the odds ratio for each site are shown in Fig. 18. No obvious associations between odds ratios and ranking of sediment contaminant concentrations were apparent for either sediment $\Sigma$ PCBs or $\Sigma$ AHs. Comparisons of odds ratios and the other chemical classes of $\sum$ DDTs, chlordane and dieldrin also did not show any systematic relationships.

It is not clear what factors are responsible for the widespread occurrence of HydVac in Puget Sound rock sole. Rock sole may be sensitive to a chemical or mixture of chemicals that has not yet been measured. Heavy metals may partially explain the occurrence of HydVac in rock sole, as some Puget Sound sites examined in the 1980 s that had high relative risks for HydVac also had high concentrations of certain metals. These included Sinclair Inlet, which had some of the highest concentrations of cadmium and mercury, and Budd Inlet, which had some of the highest sediment concentrations of arsenic (Malins et al. 1984). A shipyard for military vessels is located in Sinclair Inlet, and Budd Inlet housed a reserve military fleet until the 1970s, suggesting that chemical combinations associ- ated with vessel maintenance may be involved with the occurrence of HydVac. However, neither high metal concentrations in sedimenl nor vessel maintenance facilities were characteristic of other sites that also had high relative risks for HydVac, such as at Alki Point.

Little is known about the migratory patterns or daily movement of rock sole. It is possible that rock sole move sufficient distances to become exposed to contaminants from sources other than those present at the sites where they were captured. However, data on actual exposure levels, as determined by chemical analyses of liver tissue, is limited for rock sole. Additional liver and sediment contaminant data are needed to be more conclusive about the relationship between chemical contaminants and the occurrence of HydVac in rock sole. Nonetheless, information to date suggests that HydVac in rock sole may not be a reliable histological biomarker of response to the presence of AHs or CHs at the site of capture.

\section{Species specificity}

HydVac has been observed only in certain species of marine bottom fish. For instance, it has never been observed in English sole Parophrys vetulus, a species that has been examined in numerous laboratory and field studies conducted by our laboratory (Malins et al. 1984, Myers et al. 1987, 1990, 1992, 1994, 1997, Schiewe et al. 1991). The most readily observed histological biomarkers of contaminant effects in English sole include hepatocellular nuclear pleomorphism, megalocytic hepatosis and preneoplastic foci of cellular alteration in the liver. They are the most prevalent lesion types consistently associated with chemical contaminants in English sole tissues and sediment, and have been induced in laboratory exposure studies (Myers et al. 1987, 1990, 1992, 1994, 1997, Schiewe et al. 1991). Although not as prevalent, hepatic neoplasms in English sole are also considered histological indicators of contaminant effects, because this lesion occurs more frequently in association with contaminant exposure (Malins et al. 1984, Myers et al. 1987, 1992, 1994). In contrast, HydVac as well as neoplasms occur in the liver of winter flounder. Both of these lesion types are more prevalent in association with contaminant exposure, and are therefore considered to be histological biomarkers of contaminant effects for this species (Moore \& Stegeman 1994, Moore et al. 1996). Starry flounder and white croaker are different yet; liver neoplasms rarely occur in white croaker, and almost never occur in starry flounder even at highly contaminated sites. However, adverse health effects are evident in these species, as shown by the occurrence of contaminant-related HydVac. 
Although reasons for species differences in pathological response to contaminant exposure are not clear, the variability of lesion types that occur between species could be due, in part, to differences in life history, such as diet or length of residence at a contaminated site, or the manner in which a species metabolizes chemical contaminants. For example, the ratio of the activities of CYP1A and glutathione S-transferase (GST), which are hepatic enzymes involved in activation/detoxification of certain chemical contaminants, particularly PAHs, is markedly different in English sole and starry flounder. English sole from contaminated sites, or exposed in the laboratory to a sediment extract from a contaminated site, had significantly higher CYP1A activity, and significantly lower GST activity than starry flounder exposed in the same manner. This suggests higher activation of PAHs by CYP1A and lower detoxification of PAHs in English sole, a pattern that is consistent with the higher prevalence of lesions involved in the development of hepatic neoplasia in this species (Collier et al. 1992). In addition, immunocytochemical studies have shown that CYP1A is most intensely expressed in endothelial cells of the liver in starry flounder, while for English sole, CYP1A is most intensely expressed in hepatocytes (Anulacion et al. 1998). Such interspecies differences in cellular expression and activities of xenobiotic metabolizing enzymes may influence the types of liver cell damage observed. Further research on the cellular expression of CYP1A and relative activities of activation/detoxification enzymes in liver of other species may aid in clarifying why some species develop HydVac, while others do not. In the mean time, this information indicates that the types of lesions considered to be histological biomarkers of response to contaminant exposure should be carefully evaluated for each species, because certain histological biomarkers that are valid for one species may not be appropriate for another.

In summary, HydVac in starry flounder, white croaker and rock sole from the U.S. West Coast appears morphologically to be the same lesion as that described for winter flounder on the U.S. Atlantic Coast. HydVac is one of the most prominent histological biomarkers of response to contaminant exposure for starry flounder and white croaker. It is one of the most prevalent lesions in these species, and it is highly associated with $\mathrm{CH}$ and $\mathrm{AH}$ exposure. It also appears to be an indicator of contaminant effects for subadult starry flounder. Although HydVac also frequently occurs in rock sole, preliminary studies suggest that there is no clear relationship between the occurrence of HydVac and exposure to $\mathrm{CH}$ s or AHs for rock sole. Therefore, the utility of HydVac as a histological biomarker of response to contaminant exposure must be evaluated for each species in which it is observed.
Acknowledgements. We thank Beth Horness and Dr Linda Rhodes for reviewing this manuscript. Appreciation is expressed to Herb Sanborn, Paul Olson, Maryjean Willis, and Tom Lee for sample collection and processing of histology samples, and to many others at the Northwest Fisheries Science Center who also assisted with sample collection. Thanks also to Dr Peggy Krahn, Dr Bruce McCain, and Don Brown, who oversaw the analyses and reporting for much of the chemical data, and to other members of the Environmental Chemistry Branch for bile, tissue, and sediment chemistry analyses. Thanks also to Kari Koponen and Joy Evered for assisting with re-reading the rock sole liver histopathology sections. The samples collected during the National Benthic Surveillance Project were funded by the Office of Ocean Resources Conservation and Assessment, National Ocean Services, NOAA. Samples collected during the Marine Ecosystems Analysis (MESA) Puget Sound Program were funded by the former Office of Marine Pollution Assessment, NOAA.

\section{LITERATURE CITED}

Andrzejewska A, Szynaka B, Stokowska W, Szynaka P (1995) Does lead acetate intoxication damage acinar cell nuclei in the rat pancreas? Ultrastructural observations. Mat Med Pol 27:43-46

Anulacion BF, Myers MS, Willis ML, Collier TK (1998) Quantitation of CYP1A expression in two flatfish species showing different prevalences of contaminant-induced hepatic disease. Mar Environ Res (in press)

Augspurger TP, Herman RL, Tanacredil JR, Hatfield JS (1994) Liver lesions in winter flounder (Pseudopleuronectes americanus) from Jamaica Bay, New York: indications of environmental degradation. Estuaries 17:172-180

Bodammer JE, Murchelano RA (1990) Cytological study of vacuolated cells and other aberrant hepatocytes in winter flounder from Boston Harbor. Cancer Res 50:6744-6756

Camus AC, Wolke RE (1991) Atypical hepatic vacuolated cell lesion in white perch Morone americana. Dis Aquat Org 11:225-228

Collier TK, Singh SV, Awasthi YC, Varanasi U (1992) Hepatic xenobiotic metabolizing enzymes in two species of benthic fish showing different prevalences of contaminant associated liver neoplasms. Toxicol Appl Pharmacol 113: 319-324

Collier TK, Johnson LL, Myers MS, Stehr CM, Krahn MM, Stein JE (1997) Fish injury in the Hylebos Waterway of Commencement Bay, Washington. Northwest Fisheries Science Center Report to the Damage Assessment Center, Seattle, WA

Gardner GR, Pruell RJ, Folmar LC (1989) A comparison of both neoplastic and non-neoplastic disorders in winter flounder (Pseudopleuronectes americanus) from eight areas in New England. Mar Environ Res 28:393-397

Gray P (1954) The microtomists' formulary and guide. Blakinston, New York

Horton HF (1989) Species profiles: life histories and environmental requirements of coastal fishes and invertebrates (Pacific Northwest). Dover and rock soles. US Fish Wildl Serv Biol Rep 82

Johnson LL, Stehr CM, Olson OP, Myers MS, McCain BB, Chan SL, Varanasi U (1992) National Status and Trends Program, National Benthic Surveillance Project, Northeast Coast. Fish histopathology and relationships between lesions and chemical contaminants (1987-1989). NOAA Tech Mem NMFS-NWFC-4 
Johnson LL, Stehr CM, Olson OP, Myers MS, Pierce SM, Wigren CA, McCain BB, Varanasi U (1993) Chemical contaminants and hepatic lesions in winter flounder (Pleuronectes americanus) from the Northeast Coast of the United States. Environ Sci Technol 27:2759-2771

Johnson LL, Misitano D, Sol S, Nelson G, French B, Ylitalo G, Hom $T$ (1998) Contaminant effects on ovarian development and spawning success in rock sole (Lepidopsetta bilineatal from Puget Sound, WA. Trans Am Fish Soc (in press)

Krahn NN, Rhodes LD, Myers MS, Moore LK, MacLeod WD $\mathrm{Jr}$, Malins DC (1986) Associations between metabolites of aromatic compounds in bile and occurrence of hepatic lesions in English sole (Parophrys vetulus) from Puget Sound, Washington. Arch Environ Contam Toxicol 15: 61-67

Krahn MM, Burrows DG, MacLeod WD Jr, Malins DC (1987) Determination of individual metabolites of aromatic compounds in hydrolyzed bile of English sole (Parophrys vetulus) from polluted sites in Puget Sound, Washington. Arch Environ Contam Toxicol 16:511-522

Koza RA, Moore MJ, Stegeman JJ (1993) Elevated ornithine decarboxylase activity and cell proliferation in neoplastic and vacuolated liver cells of winter flounder (Pleuronectes americanus). Carcinogenesis 14:399-405

Love MS, McGowen GE, Westphal W, Lavenberg RJ, Martin $L$ (1984) Aspects of the life history and fishery of the white croaker Genyonemus lineatus (Sciaenidae) off California. Fish Bull US 82:179-198

Luna DG (1968) Manual of histologic staining methods of the Armed Forces Institute of Pathology, 3rd edn. McGrawHill, New York

Malins DC, McCain BB, Brown DW, Sparks AK, Hodgins HO, Chan SL (1982) Chemical contaminants and abnormalities in fish and invertebrates from Puget Sound. NOAA Tech Mem OMPA-19

Malins DC, McCain BB, Brown DW, Chan SL, Myers MS Landahl JT, Prohaska PG, Friedman AJ, Rhodes LD Burrows DB, Gronlund WD, Hodgins HO (1984) Chemical pollutants in sediments and diseases of bottom-dwelling fish in Puget Sound, Washington. Environ Sci Tech 18 $705-713$

Malins DC, Krahn MM, Myers MS, Rhodes LD, Brown DW, Krone CA, McCain BB, Chan SL (1985) Toxic chemicals in sediments and biota from a creosote-polluted harbor: relationships with hepatic neoplasms and other hepatic conditions in English sole (Parophrys vetulus). Carcinogenesis 6:1463-1469

Moore MJ (1991) Vacuolation proliferation and neoplasia in the liver of Boston Harbor winter flounder (Pseudopleuronectes americanus). Woods Hole Oceanogr Inst Tech Rep $91-28: 1-268$

Moore MJ, Myers MS (1994) Pathobiology of chemical-associated neoplasia in fish. In: Malins DC, Ostrander DK (eds) Aquatic toxicology: molecular, biochemical and cellular perspectives. Lewis Publishers, Boca Raton, p 327-386

Moore MJ, Smolowitz R, Stegeman JJ (1989) Cellular alterations preceding neoplasia in (Pseudopleuronectes americanus) from Boston Harbor. Mar Environ Res 28:425-429

Moore MJ, Stegeman JJ (1994) Hepatic neoplasms in winter flounder Pleuronectes americanus from Boston Harbor, Massachusetts, USA. Dis Aquat Org 20:33-48

Moore MJ, Shea D, Hillman RE, Stegeman JJ (1996) Trends in hepatic tumors and hydropic vacuolation, fin erosion, organic chemicals and stable isotope ratios in winter flounder from Massachusetts, USA. Mar Pollut Bull 32: $458-470$
Murchelano RA, Wolke R (1985) Epizootic carcinoma in the winter flounder ( $P_{\text {seudopleuronectes americanus). Science }}$ 228:537-589

Myers MS, Rhodes LD, McCain BB (1987) Pathologic anatomy and patterns of occurrence of hepatic neoplasms, putative preneoplastic lesions and other idiopathic hepatic conditions in English sole (Parophrys vetulus) from Puget Sound, Washington, USA. J Natl Cancer Inst 78:333-363

Myers MS, Landahl JT, Krahn MM, Johnson LL, McCain BB (1990) Overview of studies on liver carcinogenesis in English sole from Puget Sound; evidence for a xenobiotic chemical etiology I: pathology and epizootiology. Sci Total Environ 94:33-50

Myers MS, Olson OP, Johnson LL, Stehr CM, Hom T, Varanasi U (1992) Hepatic lesions other than neoplasms in subadult flatfish from Puget Sound, Washington: relationships with indices of contaminant exposure. Mar Environ Res 34:45-51

Myers MS, Stehr CM, Olson PO, Johnson LL, McCain BB, Chan SL, Varanasi U (1993) National Status and Trends Program, National Benthic Surveillance Project: Pacific Coast. Fish histopathology and relationships between toxicopathic lesions and exposure to chemical contaminants for Cycles I to V (1984-88). NOAA Tech Memo NMFS-NWFSC-6

Myers MS, Stehr CM, Olson OP, Johnson LL, McCain BB, Chan SL, Varanasi U (1994) Relationships between toxicopathic hepatic lesions and exposure to chemical contaminants in English sole (Pleuronectes vetulus), starry flounder (Platichthys stellatus) and white croaker (Genyonemus lineatus) from selected marine sites on the Pacific coast, USA. Environ Health Perspect 102:200-215

Myers MS, Anulacion BF, French B, Hom T, Collier TK (1995) Biomarker and histopathologic responses in flatfish following initial site remediation in Eagle Harbor, WA. Society of Environmental Toxicology and Chemistry Abstract Book, Second SETAC World Congress. SETAC Press, Pensacola, FL, p 96

Myers MS, Johnson LL, Hom T, Collier TK, Stein JE, Varanasi U (1998) Toxicopathic hepatic lesions in subadult English sole (Pleuronectes vetulus) from Puget Sound, Washington, USA; relationships with other biomarkers of contaminant exposure. Mar Environ Res 45:47-67

Orcutt HG (1950) The life history of the starry flounder, PJatichthys stellatus (Pallas). Calf Dept Fish Game Fish Bull 78:7-64

Papirmeister B, Gross CL, Meier HL, Petrali JP, Johnson JB (1985) Molecular basis for mustard induced vesication. Fundam Appl Toxicol 5:S134-S149

Petrali JP, Oglesby SB, Meier HL (1990a) Ultrastructural correlates of the protection afforded by niacinamide against sulfur mustard-induced cytotoxicity of human lymphocytes in vitro. Ultrastruct Pathol 14:253-262

Petrali JP, Oglesby SB, Mills KR (1990b) Ultrastructural correlates of sulfur mustard toxicity. J Toxicol Cutaneous Ocular Toxicol 9:193-214

Phillips MJ, Poucell S, Patterson J, Valencia P (1987) The liver. An atlas and text of ultrastructural pathology. Raven Press, New York

Render JA, Carlton WW (1985) Pathology of 6-aminonicotinamide toxicosis in the rabbit. Food Chem Toxicol 23: $795-803$

Schiewe MS, Weber DD, Myers MS, Jacques FJ, Reichert WL, Krone CA, Malins DC, MCCain BB, Chan SL, Varanasi U (1991) Induction of foci of cellular alteration and other hepatic lesions in English sole (Parophrys vetulus) exposed to an extract of an urban marine sediment. Can J Fish Aquat Sci 48:1750-1760 
Sloan CA, Adams NG, Pearce RW, Brown DW, Chan SL (1993) Northwest Fisheries Science Center organic analytical procedures. In: Sampling and analytical methods of the National Status and Trends Program National Benthic Surveillance and Mussel Watch Projects 1984-1992. Comprehensive descriptions of trace organic analytical methods. NOAA Tech Memo NOS ORCA 71 IV:53-96

Stehr CM (1990) Ultrastructure of vacuolated cells in the liver of rock sole and winter flounder living in contaminated environments. In: Proceedings of the XIIth International Congress for Electron Microscopy. 3:522-523

Stehr CM, Johnson L, Myers MS (1991) Severe hydropic degeneration in the liver of rock sole and starry flounder from contaminated areas of Puget Sound. In: Proceedings of Puget Sound Research 1991. Puget Sound Water Quality Authority, Olympia, WA 2:776
Stehr CM, Myers MS, Burrows D, Krahn MM, Meador J, McCain BB, Varanasi U (1997) Chemical contamination and associated liver diseases in two species of fish from San Francisco Bay and Bodega Bay. Ecotoxicology 6: $35-65$

Stein JE, Collier TK, Reichert WL, Casillas, E, Hom T, Varanasi U (1992) Bioindicators of contaminant exposure and sublethal effects: studies with benthic fish in Puget Sound, Washington. Environ Toxicol Chem 11:701-714

Vethaak AD. Wester PW (1996) Diseases of flounder Platichthys flesus in Dutch coastal and estuarine waters, with particular reference to environmental stress factors. II. Liver histopathology. Dis Aquat Org 26:99-116

Williams GM, Weisburger JH (1986) Chemical carcinogens In: Klaassen CD, Amdur MO, Doull $\mathrm{J}$ (eds) Casarett and Doull's toxicology. Macmillan Publ Co, New York, p $99-173$

Submitted: July 14, 1997; Accepted: December 4, 1997 Proofs received from author(s): February 17, 1998
Editorial responsibility: Thomas Braunbeck, Heidelberg, Germany 